\title{
MENINGKATKAN KEMAMPUAN MEMBILANG ANGKA MELALUI MEDIA \\ JAM PINTAR PADA ANAK KELOMPOK B TK NEGERI PEMBINA \\ KEC. KOTA SELATAN KOTA GORONTALO
}

\author{
Sri Wahyuningsi Laiya \\ Dosen Fakultas Ilmu Pendidikan Universitas Negeri Gorontalo
}

\begin{abstract}
ABSTRAK
Tujuan penelitian ini untuk meningkatkan kemampuan membilang angka melalui media jam pintar pada anak kelompok B TK Negeri Pembina Kec. Kota Selatan Kota Gorontalo. Penelitian ini merupakan Penelitian Tindakan Kelas (PTK) yang dilaksanakan di TK Negeri Pembina Kecamatan Kota Selatan Kota Gorontalo Provinsi Gorontalo, tepatnya di kelompok B1. Hasil penelitian menunjukkan bahwa kemampuan membilang angka pada anak Kelompok B Di TK Pembina Kecamatan Kota Selatan Kota Gorontalo dapat ditingkatkan melalui media jam pintar. Pada observasi awal terdapat 5 anak (25\%) dari 20 anak yang sudah mampu membilang angka. Setelah mengikuti siklus 1 menunjukkan peningkatan dalam kemampuan membilang angka menjadi 11 anak (60\%) dan setelah mengikuti siklus 2 terdapat peningkatan menjadi 16 anak $(80 \%)$ dari 20 orang anak untuk kemampuan membilang angka melalui media jam pintar pada anak Kelompok B Di TK Pembina Kecamatan Kota Selatan Kota Gorontalo.
\end{abstract}

Kata kunci : Kemampuan Membilang Angka, Jam pintar

\section{A.PENDAHULUAN}

Berhitung merupakan bagian dari matematika, yang sangat diperlukan dalam kehidupan sehari-hari, terutama konsep bilangan yang merupakan juga dasar bagi pengembangan kemampuan matematika maupun kesiapan untuk mengikuti pendidikan dasar. Kemampuan berhitung merupakan kemampuan melakukan pengerjaan hitung seperti menjumlahkan, mengurang, mengalikan dan membagi serta kemampuan memanipulasi bilangan- bilangan dan lambang matematika. Dalam hal ini kemampuan berhitung yang akan dilakukan mengenai kemampuan anak dalam membilang.

Membilang angka merupakan kemampuan yang harus dimiliki anak usia dini untuk bekal memahami dasar-dasar operasional yang berhubungan dengan angka. Angka memiliki posisi yang penting dalam memperkenalkan konsep bilangan. Lambang bilangan, dalam kehidupan seharihari lebih dikenal sebagai nomor atau angka. 
Konsep angka disini melibatkan pemikiran tentang beberapa jumlahnya atau berapa banyak sesuatu. Termasuk juga membilang, menjumlahkan satu tambah satu misalnya. Yang terpenting adalah mengerti konsep angka. Oleh karena itu kemampuan membilang angka perlu ditingkatkan pada anak usia dini. Syamil (2008:1) berpendapat bahwa penanaman konsep membilang angka dapat diawali dengan menggunakan "banyak-sedikit" atau besar-kecil" (tahap pra-operasional). Setelah itu tahap konkrit, diperkenalkan konsep angka, yang tujuannya agar anak tahu perbedaan antara satu dengan dua, dua dengan tiga, dan seterusnya.

Dalam pembelajaran selama ini, guru sudah melakukan berbagai cara dalam kegiatan pembelajaran misalnya menggambar di papan tulis, namun terkadang anak kurang bisa fokus terhadap kegiatan pembelajaran yang diberikan oleh guru tersebut. Terkadang guru juga memberikan pembelajaran menggunakan media, namun media yang diberikan guru sebagai alat penyampaian pembelajaran kurang menarik dan bervariasi. LKA sebagai selingan pembelajaran justru digunakan sebagai pokok kegiatan pembelajaran. Selain itu pemberian kegiatan pembelajaran membilang angka yang diberikan hanya melalui kegiatan membaca gambar di papan tulis serta pemberian tugas dengan LKA mempersulit proses evaluasi yang di lakukan guru. Penilaian yang dilakukan oleh guru hanya sekedar menilai hasil akhir tugas anak. Seharusnya guru melakukan penilaian mulai dari awal anak belajar sampai akhir.

.Jam Pintar adalah alat permainan yang terbuat dari kayu dan berbentuk persegi (bujur sangkar) yang didalamnya terdapat beberapa macam gambar yang menarik dan berwarna-warni serta terdapat angka 1-12 yang sesuai dengan jam yang sesunggunhya. Di masing-masing angka 112 ada beberapa macam gambar yang jumlahnya sesuai dengan angka yang tertera di media jam pintar 1-12. Berdasarkan hal ini, peneliti memilih jam pintar sebagai salah satu alternative untuk membantu daya berfikir anak dalam membilang angka, merangsang minat mereka dengan media yang menarik yang berbeda dengan metode dan media yang diberikan selama ini

\section{B. KAJIAN TEORITIS}

\section{Pengertian Kemampuan Kognitif}

$\begin{array}{lrr}\text { Kognitif } & \text { dalam } & \text { bahasa } \\ \text { Latin cognitio yang } & \text { berarti } & \text { pengenalan. } \\ \text { Istilah ini mengacu } & \text { baik kepada } & \text { perbuatan } \\ \text { atau proses } & \text { mengetahui } & \text { maupun } \\ \text { pengetahuan itu } & \text { sendiri. } & \text { Proses }\end{array}$


perkembangan kognitif manusia mulai berlangsung sejak ia baru lahir. Semua bayi manusia sudah berkemampuan menyimpan informasi-informasi yang berasal dari penglihatan, pendengaran, dan informasiinformasi yang diserap oleh indra-indra lain. Umumnya, kognitif dipandang cenderung pada transfer atau pemasukan ilmu pengetahuan sebanyak-banyaknya dalam diri subjek belajar, namun sesungguhnya tidak demikian. Kognitif menekankan pada tujuan atau kemampuan intelektual.

Depdiknas (2007:3), kemampuan kognitif merupakan salah satu dari bidang pengembangan oleh guru untuk meningkatkan kemampuan dan kreativitas anak sesuai dengan tahap perkembangannya. Pengembangan kemampuan kognitif bertujuan agar anak mampu megolah perolehan belajarnya, menemukan bermacam-macam alternative pemecahan masalah, pengembangan kemampuan logika matematika, pengetahuan ruang dan waktu, kemampuan memilah dan mengelompokkan, dan persiapan pengembangan kemampuan berpikir teliti.

Sementara itu Suwardiman (2003: 1) membatasi pengertian kemampuan kognitif pada anak usia dini, yakni daya atau kemampuan anak untuk berpikir dan mengamati, melihat hubungan-hubungan, kegiatan yang mengakibatkan seorang anak memperoleh pengetahuan baru yang banyak dudukung oleh kamampuan bertanya. Dengan demikian dapat diketahui bahwa perkembangan kognitif menunjukkan perkembangan dari anak berpikir. Kemampuan anak untuk mengkoordinasikan berbagai cara untuk menyelesaikan berbagai masalah dapat dipergunakan sebagai tolak ukur pertumbuhan kecerdasan.

\section{Pengertian Kemampuan Membilang}

Dalam Kamus Besar Bahasa Indonesia Edisi Ketiga (Tim Penyusun Kamus Pusat Bahasa, 2002: 126) dijelaskan bila kemampuan adalah kesanggupan, kecakapan, kekuatan; kita berusaha dengan diri sendiri. Sementara membilang yaitu menghitung dengan menyebut satu per satu untuk mengetahui berapa banyaknya (Tim Penyusun Kamus Pusat Bahasa, 2002: 150). Membilang merupakan tindakan matematika untuk menentukan berapa banyak jumlah benda yang ada.

Senada dengan penjelasan yang terdapat dalam Kamus Besar Bahasa Indonesia diatas, Shamsudin (2002: 82) menyatakan bahwa membilang adalah kegiatan berhitung dengan cara menyebutkan bilangan asli mulai dari satu sambil menunjuk benda yang hendak 
dihitung. Bilangan ditunjuk satu per satu sampai semua benda habis terhitung

Berdasarkan uraian di atas dapat disimpulkan bahwa kemampuan membilang adalah kemampuan anak untuk menyebutkan bilangan satu persatu secara urut, baik di tunjuk maupun tidak, dapat juga dengan menghafal nama bilangan secara urut sesuai dengan jumlah benda yang ada tanpa harus mengerti lambang bilangan yang menyertainya.

\section{Tahapan Kemampuan Membilang}

. Menurut Burns dan Larton (Sudono, 2000: 22-30) mengemukakan bahwa, kelompok matematika dapat diperkenalkan mulai dari usia 3-6 tahun adalah kelompok bilangan (membilang, aritmatika dan berhitung). Penguasaan masing-masing kemampuan anak tersebut selalui melalui tiga tingkat penekanan tahapan yaitu :

1. Tingkat pemahaman konsep, anak akan memahami konsep melalui pengalaman bekerja dan bermain dengan benda konkret.

2. Tingkat menghubungkan konsep konkrit dengan lambang bilangan. Setelah konsep dipahami anak, guru anak mengenalkan konsep benda konkret ke lambang konsep. Hal ini lah yang mendasari kartu bergambar sebagai lambing dari konsep benda konkret.

3. Tingkat lambang bilangan, anak di berikan kesempatan untuk menulis bilangan atas konsep-konsep konkret yang mereka pahami.

Sedangkan menurut Mudjito (2007:10) Tahapan kemampuan membilang untuk anak usia 5-6 tahun mengacu pada tahapan permainan berhitung di Taman Kanak-kanak yang berdasarkan teori dilakukan melalui tiga tahapan penguasaan membilang di jalur matematika yaitu:

a. Penguasaan konsep

b. Masa Transisi

c. Lambang

Lebih lanjut Mudjito (2007: 10-11) menagatakan bahwa Standar Perkembangan Anak di antaranya: a) menyebut dan membilang 1 sampai 20; b) mengenal lambang bilangan; c) menghubungkan konsep bilangan dengan lambang bilangan; d) membuat urutan bilangan dengan bendabenda; serta e) membedakan dan membuat dua kumpulan benda yang sama jumlahnya, yang tidak sama, lebih sedikit, dan lebih banyak.

Berikut ini adalah indikator lingkup perkembangan kognitif bidang konsep 
bilangan, lambang bilangan dan huruf anak usia 5-6 tahun menurut Permendiknas No. 146 pada kurikulum 2013 tahun 2014, yakni:

a. Menyebutkan angka bila diperlihatkan lambang bilangannya

b. Menyebutkan jumlah benda dengan cara menghitung.

\section{Pengajaran Kemampuan}

\section{Membilang..}

Penyampaian pembelajaran

membilang dapat diberikan melalui dua cara. Membilang buta (membilang tanpa objek yang dibilang), yaitu menyebutkan bilangan menurut urutan bilangan tertentu atau urut mulai dari 1-20 dan membilang bermakna yaitu membilang dengan menentukan banyaknya anggota himpunan dengan cara membilang. Kegiatan itu bisa di lakukan dengan bernyanyi atau menggunakan media yang menarik (Tarigan, 2006: 19).

Penyampaian pembelajaran membilang dalam penelitian ini mengacu pada pengenalan permainan berhitung permulaan, sebahgai berikut (Mudjito, 2007: 2):

1. Permainan membilang diberikan secara bertahap, diawali dengan membilang benda-benda atau pengalaman peristiwa konkret yang dialami melalui pengamatan terhadap alam sekitar.

2. Pengetahuan dan keterampilan dalam permainan membilang diberikan secara bertahap menurut tingkat kesukarannya, misalnya dari yang konkret ke yang abstrak, mudah ke sukar, dan dari sederhana ke yang lebih kompleks.

3. Permainan membilang akan berhasil jika anak-anak diberikan kesempatan berpartisipasi dan dirangsang untuk menyelesaikan masalah sendiri.

4. Permainan membilang membutuhkan suasana menyenangkan dan memberikan rasa aman serta kebebesan bagi anak. Untuk itu dapat diperlukan alat peraga atau media yang menyenangkan, sesuai dengan benda aslinya (tiruan), menarik dan bervariasi, mudah digunakan, dan tidak membahayakan.

5. Bahasa yang digunakan dalam kosep membilang sebaiknya bahasa yang sederhana dan jika memungkinkan mengambil contoh yang terdapat di lingkungan sekitar anak. 
6. Dalam permainan membilang anak dapat dikelompokkan sesuai tahap penguasaannya yaitu tahap konsep, masa transisi, dan lambang.

7. Dalam mengevaluasi hasil perkembangan anak harus dimulai dari awal sampai akhir kegiatan.

\section{Indikator Kemampuan Membilang Angka}

Menurut Mudjito, (2007: 10-11)

indikator dari kemampuan membilang angka yakni :

a. Menyebut dan membilang 1 sampai 20

b. Mengenal lambang bilangan

c. Menghubungkan konsep bilangan dengan lambang bilangan

d. Membuat urutan bilangan dengan benda-benda

e. Membedakan dan membuat dua kumpulan benda yang sama jumlahnya, yang tidak sama, lebih sedikit, dan lebih banyak.

\section{Media Jam Pintar}

Jam Pintar adalah alat permainan yang terbuat dari kayu dan berbentuk persegi (bujur sangkar) yang didalamnya terdapat beberapa macam gambar yang menarik dan berwarna-warni serta terdapat angka 1-12 yang sesuai dengan jam yang sesunggunhya, Berda (2017: 75). Di masing-masing angka 1-12 ada beberapa macam gambar yang jumlahnya sesuai dengan angka yang tertera di media jam pintar 1-12. Jam pintar digunakan untuk belajar dan hitung sederhana melalui permainan yang mendidik. Dengan menggerakkan angka kegambar yang sesuai maka anak belajar mengenal angka sekaligus berhitung. Penggunaan Media Jam Pintar dapat digunakan untuk melatih gerakan tangan dan mencari jejak, sehingga menarik minat anak untuk belajar berhitung sekaligus bermain.

Menurut Berda (2017: 78) Jam pintar digunakan untuk belajar angka dan hitung sederhana melalui permainan mendidik. Dengan menggerakkan angka kegambar yang sesuai maka anak belajar mengenal angka sekaligus berhitung sederhana. Gerakan tangan untuk menempatkan angka ke tempat yang sesuai akan merangsang motorik halus anak dan konsentrasi, serta koordinasi tangan-mata.

Fungsi Media Jam Pintar adalah a) mengasah otak anak, b) memperkuat konsentrasi, c) melatih menyelesaikan masalah, d) melatih koordinasi tangan dan mata anak. 


\section{Langkah-Langkah Penggunaan Media Jam Pintar}

Menurut Berda (2017: 78) langkahlangkah dalam penggunaan media jam pintar yakni sebagai berikut :

a. Tunjuk angka salah satu yang terdapat pada media jam pintar yang kita inginkan/sesuai peraturan.

b. Cari dan hitung terlebih dahulu dimana yang cocok antara jumlah gambar dengan angka yang kita pegang.

c. Apabila sudah menemukan dimana letak gambar yang sesuai dengan angka yang kita pegang.

d. Lalu tempatkan angka tersebut pada pasangan gambar yang sesuai dengan angka yang kita pegang.

e. Apabila sudah menemukan dimana letak pasangan bilangannya, angka tersebut kita letakkan pada posisi yang tepat.

\section{Strategi Pembelajaran Menggunakan} Media Jam Pintar

Dalam pembelajaran menggunakan jam pintar maka strategi yang digunakan akan menghasilkan:

a. Agar anak mampu mengembangkan daya persepsinya berdasarkan apa yang dilihat, didengar dan dirasakan, sehingga anak akan memiliki pemahaman konsep bilangan yang utuh dan komprehesif.

b. Agar anak mampu melatih ingatannya terhadap semua peristiwa dan kejadian yang pernah dialaminya.

c. Agar anak mampu melatih ingatannya terhadap semua peristiwa dan kejadian yang pernah dialaminya.

d. Agar anak mampu mengembangkan pemikiran-pemikirannya dalam rangka menghubungkan satu peristiwa dengan peristiwa lainnya.

e. Agar anak mampu melakukan penalaranpenalaran, baik yang terjadi secara alamiah (spontan), maupun melalui proses ilmiah (percobaan).

f. Agar anak mampu memecahkan persoalan hidup yang dihadapinya, sehingga pada akhirnya anak akan menjadi individu yang mampu menolong dirinya sendiri. Berda ( 2017: 79).

10. Penanaman Konsep Bilangan dengan Menggunakan Media Jam Pintar 
Untuk konsep dasar yang dipelajari atau diperoleh anak pra sekolah melalui media jam pintar. Bahwa pada usia pra sekolah anak diharapkan menguasai berbagai konsep seperti warna, dan angka. Pengetahuan akan konsep-konsep ini jauh lebih mudah diperoleh melalui penggunaan media jam pintar. Dimana anak usia prasekolah mempunyai rentang perhatian yang terbatas dan masih sulit diatur atau masih sulit belajar dengan serius. Tetapi bila pengenalan konsepkonsep tersebut dilakukan sambil bermain, maka anak akan merasa senang, tanpa ia sadari ternyata ia sudah banyak belajar. Bermain dengan menggunakan alat permainan edukatif (jam pintar) akan mendapatkan masukan pengetahuan yang akan diingat oleh anak untuk memenuhi naluri bermainnya. Menurut Zainal Aqib (2009:46) alat permainan edukatif (APE) adalah alat bermain yang dapat melakukan kegiatan rangsangan dan dorongan memperlancar perkembangan kemampuan anak. Setiap anak senang dan menyukai bermain, dengan bermain mereka akan menemukan pengalaman, ide-ide yang dapat memotivasi mereka untuk belajar. Penggunaan media jam pintar membuat anak dapat mengenal lambang bilangan dan juga warna serta gambar. Dalam media jam pintar terdapat

Bermacam-macam gambar dan warnawarna yang mencolok atau cerah, sehingga anak akan tertarik melalui permainan ini. Anak akan dilatih melalui panca inderanya supaya peka terhadap sesuatu yang ada dilingkungannya dan mengembangkan seluruh aspek perkembangan anak.

\section{Kajian Penelitian yang Relevan}

Kajian penelitian yang relevan dengan penelitian ini yakni penelitian yang dilakukan oleh Nunik Sulistiati Tahun 2014 dengan judul meningkatkan kemampuan membilang angka 1-10 melalui metode bermain kartu angka pada anak kelompok A3 di TK ABA Ketanggungan Yogyakarta. Hasil penelitian menunjukkan bahwa kemampuan membilang pada anak kelompok A3 TK ABA Ketanggungan Yogyakarta dapat ditingkatkan melalui metode bermain dengan kartu angka

Yang menjadi persamaan dengan penelitian ini yakni mengenai kemampuan membilang angka dan metode penelitian yakni Penelitian Tindakan Kelas. Adapun yang menjadi perbedaan yakni penggunanaan media jika pada penelitian Nunik Sulistati media yang digunakan kartu 
angka sedangkan pada penilitian ini menggunakan media jam pintar.

\section{METODE PENELITIAN}

Penelitian ini merupakan suatu Penelitian Tindakan Kelas (PTK) yang dilaksanakan di TK Negeri Pembina Kihadjar Dewantoro Kec. Kota Selatan Kota Gorontalo. Jumlah Pendidik dan tenaga Kependidikan di TK Negeri Pembina Kihadjar Dewantoro ini berjumlah 9 )rang. Yang terdir dari 3 orang PNS 6 orang guru honor

\section{Prosedur Penelitian}

Pelaksanaan penelitian ini dilakukan pada setiap penelitian dimulai, adapun kegiatan-krgiatan yang dilakukan sebagai berikut:
a. Tahap perencanaan/ Persiapan
b. Tahap Pelaksanaan Tindakan
c. Tahap Pemantauan dan Evaluasi
d. Tahap Refleksi

\section{HASIL PENELITIAN DAN PEMBAHASAN}

Berdasarkan hasil kegiatan penelitian tindakan kelas yang dilaksanakan pada siklus I dan siklus II dapat dijelaskan bahwa kemampuan membilang angka melalui media jam pintar pada anak kelompok B TK Pembina Kecamatan Kota Selatan Kota Gorontalo terjadi peningkatan yang signifikan.

Gambaran umum tentang meningkatnya kemampuan membilang angka melalui media jam pintar pada anak kelompok B TK Negeri Pembina Kecamatan Kota Selatan Kota Gorontalo di deskripsikan sebagai berikut:

1. Hasil observasi awal dari 20 orang anak yang dikenakan tindakan terdapat 5 anak (25\%) yang mampu membilang angka dengan baik dan masih 15 anak (75\%) yang belum mampu membilang angka. Rendahnya kemampuan membilang angka pada anak kelompok B diketahui setelah dilakukan pengamatan peningkatan kemampuan membilang angka pada anak kelompok B TK Pembina Kecamatan Kota Selatan Kota Gorontalo yang dilakukan melalui media jam pintar.

2. Hasil siklus I dari 20 orang anak yang dikenakan tindakan terdapat 12 orang anak atau (60\%) yang mampu mengenal lambang bilangan dari angka 1-20 dengan media jam pintar dan 10 orang anak atau (50\%) yang mampu menghubungkan konsep angka dengan lambang bilangan 1-20 melalui media 
jam pintar. Jadi rata - rata peningkatan kemampuan membilang angka pada anak kelompok B TK Pembina Kecamatan Kota Selatan Kota Gorontalo menjadi 11 orang anak atau (55\%) yang mampu.

3. Hasil siklus II dari 20 orang anak yang dikenakan tindakan terdapat 17 orang anak atau (85\%) yang mampu mengenal lambang bilangan dari angka 1-20 dengan media jam pintar dan 16 orang anak atau (80\%) yang mampu menghubungkan konsep angka dengan lambang bilangan 1-20 melalui media jam pintar. Jadi rata - rata peningkatan kemampuan membilang angka pada anak kelompok B TK Pembina Kecamatan Kota Selatan Kota Gorontalo menjadi 16 orang anak atau (80\%) yang mampu. Dari keseluruhan jumlah anak yang diberikan tindakan, masih tersisa 4 orang anak atau $20 \%$ yang belum mampu membilang angka, oleh karena itu diperlukan tindakan dan latihan yang berkelanjutan agar mereka bisa menguasainya.

\section{KESIMPULAN}

Berdasarkan hasil penelitian dan pembahasan disimpulkan bahwa penggunaan media jam pintar dapat meningkatkan kemampuan membilang anak kelompok B di TK Negeri Pembina Kecamatan Kota Selatan Kota Gorontalo. Pengajaran kemampuan membilang angka dapat dilakukan dengan berbagai macam cara baik menggunakan media abstrak maupun yang konkrit. Namum untuk meminimalisir ketidakmampuan anak dalam menerima materi maka digunakan media yang dapat dilihat oleh anak. Sehingga saat anak menerima materi yang disajikan oleh guru yang didesain dengan media pembelajaran maka dengan mudah anakanak dapat memahaminya. 


\section{REFERENSI}

http://syifarhs.blogspot.co.id/2016/12/penge

rtian-kemampuan-kognitif-afektif.html

http://pembelajaran-

pendidikan.blogspot.co.id/2012/04/pengerti

an-kemampuan-kognitif.html

Berda Asmara. 2017. Penggunaan Media Jam Pintar Dalam Meningkatkan Pemahaman konsep Bilangan 1 - 20 Pada Anak Kelompok B di TK Khadijah Wonokromo Surabaya. Education and Human Development Journal, Vol. 02. No. 01, April 2017

Hollands. 2002. Kamus Matematika. (Alih Bahasa: Naipospos Hutauruk). Jakarta: Erlangga.

Izzaty, Rita Eka. Dkk. 2008. Perkembangan Peserta Didik. Yogyakarta: UNY Press.

Karim, Muchtar. 2003. Pendidikan Matematika I. Jakarta: Departemen Pendidikan dan Kebudayaan.

Mudjito AK. 2007. Pedoman Pembelajaran Berhitung di Taman Kanak-kanak. Jakarta: Departeman Pendidikan Nasional.

Patmonodewo, Soemiarti. 2003. Pendidikan Anak Prasekolah. Jakarta: Pusat Perbukuan Depdikbud dan PT Rineka Cipta.

Ramli, M. 2005. Pendampingan Perkembangan Anak Usia Dini. Jakarta: Depertemen Pendidikan Nasional.

Santrock, J.W. 2002. Life-Span Development: Perkembangan Masa Hidup Jilid I. (Alih Bahasa: Juda Damanik \& Acmad Chusairi). Jakarta: Penerbit Erlangga.
Seefeldt \& Wasik, B.A. 2008. Pendidikan Anak Usia Dini: Menyiapkan Anak Usia Tiga, Empat, dan Lima Tahun Masuk Sekolah. (Alih bahasa: Pius Nasar). Jakarta: Indeks.

Shamsudin, Baharudin. 2002. Катиs Matematika Bergambar. Jakarta: Gramedia Widiasarana Indonesia.

Simanjuntak, Lisnawati, dkk. 2001. Metode Mengajar Matematika Jilid 1. Jakarta: PT. Rineka Cipta.

Suardiman. Siti Partini. 2003. Metode Perkembangan Daya Pikir dan Daya Cipta untuk Anak Usia Dini. Yogyakarta: Fakultas Ilmu Pendidikan, UNY.

Sudono, Anggani. 2000. Sumber Belajar dan Alat Permainan untuk Pendidikan Anak Usia Dini. Jakarta: PT. Grasindo.

Susanto, Ahmad. 2011. Perkembangan Anak Usia Dini. Jakarta: Kencana Perdana Media Group.

Suyanto. Slamet. 2005. Pembelajaran untuk Anak TK. Jakarta: Departemen Pendidikan Nasional.

Syamil. 2008. Kemampuan Membilang Anak Usia Dini. Bandung: Angka

Tarigan, Daitin. 2006. Pembelajaran Matematika Realistik. Jakarta: Departemen Pendidikan Nasional, Direktorat Jenderal Pendidikan Tinggi, Direktorat Ketenagaan.

Tim Penyusun Kamus Pusat Bahasa. 2005. Kamus Besar Bahasa Indonesia Edisi Ketiga. Jakarta: Balai Pustaka. 
